\title{
A Practice of Reading Assessment in a Primary Classroom
}

\author{
Ruiting $\mathrm{Wu}$ \\ Faculty of Education, University of Tasmania, Launceston, TAS, Australia \\ Ruijuan $\mathrm{Wu}$ \\ Hebei United University, Tang Shan, Hebei, China \\ Jinjin $\mathrm{Lu}$ \\ Faculty of Education, University of Tasmania, Launceston, TAS, Australia
}

\begin{abstract}
Assessment is very important to monitor students' learning progress in schools. This study focuses on reading assessment in a primary classroom. This study aimed to discover the effect of the reading assessment plan on monitoring the students' learning progress. The participants were 21 primary students of mixed gender. The data gathering consisted of observation, teacher-student interactions, running records, using tests, and keeping reading profiles. Qualitative approach was used to analyse the data. The findings confirmed that careful planning was essential for effectively assessing students' study and the students' different English reading and writing abilities should be considered in deciding the difficulty of the plan. A number of recommendations have been made in relation to this study to assist primary teachers to make a reading assessment plan. The findings from this study have the potential to assist current and future pre-service teachers and primary school teachers in identifying effective and appropriate assessing strategies to enhance students' academic achievements.
\end{abstract}

Index Terms — assessment strategy, planning, practise, reading assessment

\section{INTRODUCTION}

Assessment, according to the Curriculum Corporation (1997), is "the process through which teachers identify, gather and interpret information about student achievement and learning". It provides "information teachers need in order to improve student learning" (Curriculum Corporation, 1997, p. 1; Department of Education, Tasmania, 2005, p. 8). As assessment fulfills a range of purposes for the teacher and students, e.g., by providing information about students' progress and learning; evaluating the success of teaching approaches, and determining students' achievement (Curriculum Corporation, 1997; Weeden, Winter \& Broadfoot, 2002), it should be included in the everyday primary classroom.

The learning of literacy in primary schools consists of four basic skills: listening, speaking, reading, and writing (Campbell \& Green, 2006). The reading skill is increasingly seen as one of the most important skills. It determines both performance in other subject areas, such as science and the humanities, at the primary stage and also academic achievement at a much later stage (Reynolds, 1998). Studies of Sammons, Thomas and Mortimore (1997) indeed showed correlations as high as $80 \%$ between children's performance on reading at age seven and their subsequent achievement scores. Assessing reading skill then appears very significant in primary classrooms.

Successful assessment in the classroom involves careful planning, which provides the teacher with the clear direction towards the goals that the assessment should achieve. As Badger, Dilena, Peters, Webster, and Weeks (1991) suggested, "If your approach to assessment is going to be an effective and manageable means of fostering students' learning and helping you to evaluate your literacy program then you need to plan your practices in a systematic and decisive way" (p. 3). Careful planning helps the teacher to be clear with specific procedures in assessing students' academic achievement. The plan needs to be applied to empirical practices in order to achieve its worthiness. Frequently reflecting on practices enables the teacher to find out what strategies have worked well and what areas still need to improve. This study thus follows the procedure of planning, practising and reflecting on reading assessment in a primary classroom.

This study provides a brief literature review on reading assessment; an overview of the plan of reading assessment; how and why the planned reading assessment strategies will be used; findings and discussion; reflections, and conclusions.

\section{Literature REVIEW AND the OVERVIEW OF THE PlAn OF READING ASSESSMENT}

In literature, the importance of reading assessment has been examined by many researches (Little, 1978; Raggett, Tutt \& Raggett, 1979; Rowe, 2006). Assessment has been recognized as "a crucial component of the effective teaching 
of reading" by Winch, Johnston, March, Ljungdahl, and Holliday (2006, p. 135). Assessment in reading is also increasingly important in primary schools. According to Winch, Johnston, March, Ljungdahl, and Holliday (2006):

School and school systems throughout Australia are now required to report to the Federal Government about the achievement of their students in relation to nationally agreed benchmarks in literacy. Schools and school systems gather assessment evidence to assist in making judgments about the achievement of individual students and particular groups of students, the targeting of resources, and the effectiveness of program. (p. 138)

Due to the importance of reading assessment, many forms and strategies of assessing students' reading skill are made available for teachers to choose for use in the classroom. Nevertheless, what reading assessment strategies should be chosen as the most appropriate for the primary classroom? This study plans to focus on assessing students' reading accuracy, fluency, and comprehension, which have been commonly agreed by investigators as "three empirical dimensions of reading skill” (Turner, 1997, p. 50). The activity strategies will involve word recognition lists and sentence completion tests, oral reading, reading and retelling, text comprehension tests, reading self-assessment, and reading portfolios. The following organizational strategies will be used to assist in the gathering of reading assessment data: observation, teacher-student interactions, running records, using tests, and keeping reading profiles. The table below (Table 1) shows the overview of the plan of reading assessment on the dimensions of what the assessment strategies will be used, what tools will be used to assist in collecting data, and for what aims of reading assessment that these strategies will be used.

TABLE I

OVERVIEW OF READING ASSESSMENT

\begin{tabular}{|l|l|l|}
\hline Assessment strategies & Tools of collecting data & Aims of reading assessment \\
\hline $\begin{array}{l}\text { Word recognition lists and } \\
\text { sentence completion tests }\end{array}$ & $\begin{array}{l}\text { Everyday word recognition and sentence comple- } \\
\text { tion } \\
\text { Weekly word tests and sentence completion tests }\end{array}$ & $\begin{array}{l}\text { Assessing reading accuracy and compre- } \\
\text { hension }\end{array}$ \\
\hline Text comprehension tests & $\begin{array}{l}\text { Multiple choices } \\
\text { Matching } \\
\text { True-false } \\
\text { Cloze } \\
\text { Short-answers } \\
\text { Summarizing information }\end{array}$ & Assessing reading comprehension \\
& Read aloud to the teacher & \\
\hline Oral reading & $\begin{array}{l}\text { Silent reading or listening to a narrative } \\
\text { Orally retelling or commenting on it in their own } \\
\text { werds }\end{array}$ & $\begin{array}{l}\text { Assessing reading accuracy, fluency, and } \\
\text { comprehension }\end{array}$ \\
\hline Text comprehension tests & $\begin{array}{l}\text { Multiple choices } \\
\text { Matching } \\
\text { True-false } \\
\text { Cloze } \\
\text { Short-answers } \\
\text { Summarizing information }\end{array}$ & Assessing reading comprehension \\
& $\begin{array}{l}\text { Keeping records using reading logs } \\
\text { Writing journals }\end{array}$ & \\
\hline Reading self-assessment & $\begin{array}{l}\text { Assessing reading accuracy, fluency, and } \\
\text { comprehension }\end{array}$ \\
\hline
\end{tabular}

\section{Planning Reading Assessment Strategies: How And Why?}

This section will briefly describe how and why these reading assessment strategies will be used. As "reading is a very complex skill" (Beech \& Singleton, 1997, p. 226) and each assessment strategy has its own function which cannot be taken place by any other strategies, effective reading assessment needs to cover a wide range of strategies, in order to provide the teacher and students with valid and reliable students' learning progress and academic achievements. This is supported by the Australian Educational Research Association (as cited in the Department of Education of Victoria \& Early Childhood Development, 2007, p. 19), which states that "no decisions about an individual's education should be made on the basis of test scores alone; there is a need for multiple sources of evidence". The Australian Curriculum Studies Association (as cited in Brady \& Kennedy, 2005, p. 23) also suggested that "assessment should use a range of strategies".

Summative assessment emphasizes on the purposes for review, transfer and certification, while formative assessment addresses on assisting learning (Weeden, Winter, \& Broadfoot, 2002). As Owen (1992, p. 95) pointed out, "To improve standards rather than simply to record and report them, assessment procedures must be formative". Edwards-Groves (2003, p. 57) also noted that "assessments needs to be regular and ongoing".

The planed reading assessment will thus adopt a range of strategies in a variety of formal and informal contexts, including formative assessment and summative assessment. The informal and formative assessment can be integrated into students' everyday activities and tasks, while the formal and summative assessment can provide with specific report at the end of a learning sequence, course or unit. Most strategies employed in this plan can be conducted both informally and formally. The teacher gives formative feedback when testing students informally, and gives a specific score and comments when testing formally. Details of each strategy in this plan are demonstrated as follows: 


\section{A. Word Recognition Lists and Sentence Completion Tests}

Word recognition lists and sentence completion tests can be tested regularly. Everyday, students can read word lists loud to the teacher and complete sentences by filling in the correct word. The teacher gives the immediate oral and written formative feedback. The formal word tests and sentence completion tests can be conducted weekly. A reading accuracy score will be given according to their performance. For example, the total score is $100 \%$ and there are 10 questions in total, then each question weighs 10\%. However, Owen (1992, p. 96) argued that "word recognition lists and sentence completion tests are highly reliable in test-retest situations, but tell us little about the child's success on a range of everyday reading tasks". Other assessment strategies are thus required.

\section{B. Text Comprehension Tests}

As for the text comprehension tests, students read the text silently then answer questions silently in a prescribed amount of time, such as multiple choices, matching, true-false, cloze, short-answers, and summarizing information. Tests of silent reading comprehension are supported by Beech and Singleton (1997), who claimed that reading comprehension cannot be measured accurately when someone has been asked to read aloud, since the process of dealing with correct pronunciation and expression can interfere with comprehension. This test can also use a total score of $100 \%$ and each question weighs a certain percentage to measure students' performance. Tests measured by using a specific score to show correct answers can accurately show students' learning achievement. Both teachers and students will thus be more clearly aware of the teaching and learning progress.

\section{Oral Reading}

Oral reading allows students to read the text aloud to the teacher. It can fulfill many requirements of teachers when the test of oral reading is conducted informally, e.g., "being easy to test; providing useful information; being individualized" (Senior, 1979, p. 180). When the test is conducted formally, a reading accuracy and a reading fluency score will be derived from their reading performance. The teacher will focus on observing "students' reading omission, repetition, substitution, insertion, hesitation, and correction" (Senior, 1979, p. 180). For example, if the student misreads a word, or hesitates for longer than a prescribed amount of time, the teacher takes note and takes off a certain percentage from the total score of $100 \%$, the teacher may also supply the correct word and give him/her the immediate oral formative feedback.

\section{Reading and Retelling}

The strategy of reading and retelling refers to that "students silently read or listen to a narrative and then orally retell or comment on it in their own words" (Curriculum Corporation, 1997, p. 22). The following criteria can be used to test students' reading accuracy, fluency and comprehension, whether the student (Curriculum Corporation, 1997, p. 22):

- relates the information in their own words;

- identifies key events or features of the text;

- clearly and logically sequences ideas.

\section{E. Reading Self-assessment}

Reading self-assessment was suggested by the Australian Curriculum Studies Association (as cited in Brady \& Kennedy, 2005) as one of the most important principles when adopting assessment strategies. Students need to monitor their own progress and move towards successful independent learning. Learning will be more effective when the learners actively engaged and make more contribution to their own learning (Bowell \& Heap, 2001). Research (Kulm, 1994) suggests that "students who are able to evaluate their own thinking and learning processes have higher achievement" (p. 73). As students will not automatically have the skills to undertake self-assessment, it is important for the teacher to provide models and demonstrations of learning, e.g., samples of learning logs and journals for students to record their reading progress (see Appendix A and B).

\section{F. Reading Portfolios}

Reading portfolios keep all the reading work samples of students over time. It shows a student's development in learning reading skill on accuracy, fluency, and comprehension. The teacher gives a summative assessment and comment on students' reading progress based on the work samples collected in their reading portfolios. The greatest advantage of portfolios is the creation of the diagnostic, formative, and summative record at the same time (Kulm, 1994). Through assessing students' reading portfolios, the teacher can get a rich and comprehensive picture of students' reading abilities, and can communicate the findings with students and parents.

\section{FINDINGS AND DisCUSSION}

In this study, the Year Three classroom where the planned reading assessment was applied into practice consisted of twenty-one students, eleven boys and ten girls. All of them were around ten years old. Every morning, the teacher listened to some students reading picture books aloud one by one. She gave the students immediate formative feedback. Notes were also taken in the form of comments or daily assessments as evidence of the improvement of students' 
reading skill. Tests of word recognition lists, sentence completion, and text comprehension were used twice a week this term. Reading self-assessment was undertaken by students writing a journal named Me as a reader (see Appendix B: Guideline 1). Reading portfolios were recorded for all students to keep track their everyday learning progress. Next will report and analyze the findings in relation to the strategies used in this plan. When citing a participant, the participant will be coded as "P".

\section{A. Tests of Word Recognition Lists, Sentence Completion, and Text Comprehension}

Students were tested twice a week on word recognition lists, sentence completion, and text comprehension. The classroom teacher followed a word list book entitled 100 Magic Words to test students' word recognition, and used a reading comprehension book to test sentence and text comprehension. In each test, students were given 10 words to read aloud to the teacher, and a reading text comprehension sheet to complete. The teacher walked from one student to another, gave the student immediate feedback and took note on his or her performance. These performances were recorded in their own portfolio. Nearly all students in this class completed tasks of the same level in the textbooks so that they could be tested at the same time in the class.

\section{B. Oral Reading and Retelling}

Students were divided into different reading levels according to their results in a reading assessment at the beginning of the year. Everyday students were given one or two picture books in their levels to read aloud to the teacher individually. If the student had read all the books in that level, he/she would then move to read picture books in the next level. Listening to students reading aloud and retelling were ongoing assessment strategies that the classroom teacher usually used. They built the context of the assessment and helped the teacher to gain a general idea on the development of students' reading skills. Most of students in this class (17 out of 21) could read well and regularly moved to read books of next level. Only 4 out of 21 students ( 3 boys and 1 girl) struggled to read fluently. They were even one or two levels behind others. This was because these students often missed the classes for the reasons of travelling, holiday or sickness.

\section{Reading Self-assessment}

During one lesson, students were required to self-assess their reading skill by writing a journal named Me as a reader (see Appendix B: Guideline 1). Through reflecting and answering the guided questions, students gained a better understanding on what they viewed themselves as readers and how to improve their reading skill. Most of students (15 out of 21) completed this self-assessment journal. Five students ( 2 boys and 3 girls) even did beautifully. One participant responded with the following statement:

I think I am a good reader. I feel like that I can read everything. But sometimes I do not understand them. I like reading funny stories, because they make me laugh. I have found that books without pictures are difficult to read, because it makes me bored by too many words. I want to read 100 books this year. I think I need my parents to explain the meaning of the books ( $P$ A).

This student has developed a high level of reading skill and she also has an ability of self-assessing her development. This can be seen from the following features in her writing:

- very neat handwriting;

- very good grammar;

- only a few spelling mistakes;

- very logical to express ideas;

However, some students (about 6 students) found it difficult to complete this assessment. They even could not complete this journal. This was shown by a response of a participant:

I think I am a reader. I like reading stories. I think I need help $(P B)$.

This might be because they were not familiar with self-assessing reading skill in this way. Another reason might be due to their low ability in writing.

\section{Reading Portfolios}

Students' reading performances were recorded in their portfolio, which included notes made through reading aloud and retelling, scores from tests, and journals by writing a reading self-assessment. Students' portfolios will be presented to their parents at the end of term. Their parents could also check their child's portfolio at any time in order to know their child's learning progress. The teacher divided students into groups according to the records of their portfolio in order to work on the same problems they had. The students thus did not have to work on the areas that they had already known. This group work was done once a week.

\section{RECOMMENDATIONS}

Based on the students' performances on reading assessment in this practice, this section will make recommendations to enhance the effectiveness of assessing students' reading abilities and learning progress. They are listed as follows: 
1. When planning an assessment, students' diverse backgrounds and abilities have to be considered. The difficulty of the assessment has to accord with students' abilities. It should not be so easy for students to lose interest, while it should not be too difficult for them to complete.

2. The real practice may not be as successful as what has expected. A wide range of situations should be considered as fully as possible when planning. The teacher also has to prepare to deal with many unpredictable situations.

3. One assessment strategy can never be effective in monitoring students' learning. A wide range of assessment strategies should be used in order to closely reflect students' reading ability.

4. More assessment strategies need to be further researched in order to suit students' diverse backgrounds.

\section{CONCLUSION}

This study has explored the reading assessment in a primary classroom through the procedure of planning, practising and reflecting. In conclusion, this reading assessment was planned well. It covered both formative and summative assessment, and evaluated both in general and specific. It assessed students' reading accuracy, fluency, and comprehension, which were the most important dimensions of reading skills that the teacher needs to know about students' learning. Most of students performed well, and gender differences were not found obvious in the performances of this assessment. The findings confirmed that careful planning was essential for effectively assessing students' learning and the students' different English reading and writing abilities should be considered in deciding the difficulty of the plan. This study thus made many recommendations to assist primary school teachers to make a reading assessment plan.

This research could be further developed if the following two issues, which arose from this study, were explored. One is that more strategies can be planned, practised, and evaluate their effectiveness. The other is that this reading assessment plan is practised in different year level classrooms in order to see if this leads to different results. An extensive amount of research still needs to be undertaken in order to provide teachers with the most effective assessment strategy to monitor students' learning progress. This would be a worthwhile goal particularly given the longterm benefits for both students and teachers.

\section{APPENDIX A. GUIDELINES FOR KEEPING RECORDS USING LEARNING LOGS}

Guideline 1: My reading record

TABLE II

MY READING RECORD

\begin{tabular}{|c|c|c|c|c|c|}
\hline $\begin{array}{l}\text { Titles and authors } \\
\text { of books }\end{array}$ & $\begin{array}{l}\text { Read to } \\
\text { Signed }\end{array}$ & $\begin{array}{l}\text { Completion and } \\
\text { pages: } \\
\text { Signed }\end{array}$ & Genre & $\begin{array}{l}\text { Rating: } \\
\text { Excellent } \\
\text { Good } \\
\text { Satisfied }\end{array}$ & $\begin{array}{l}\text { Feelings about the } \\
\text { book }\end{array}$ \\
\hline & & & & & \\
\hline & & & & & \\
\hline & & & & & \\
\hline & & & & & \\
\hline & & & & & \\
\hline
\end{tabular}

Guideline 2: Drop everything and read (Rhodes, 1993, p. 46)

How much time did you spend reading during DEAR time today?

a) All the time; b) Most of the time; c) Some of the time; d) Not at all

If you did not spend all the time reading, why didn't you?

What will help you so that you will spend all your time reading next time we have DEAR time?

\section{APPENDIX B. GUIDELINES FOR REFLECTING READING JOURNALS}

Guideline 1: Me as a reader (Badger, Dilena, Peters, Webster, and Weeks, 1991, p. 68)

What do you think about yourself as a reader?

What kinds of books do you enjoy? Why?

What kinds of books do you find difficult? Why?

What challenges in reading could you set yourself this year?

What help will you need to achieve them?

What will you need to do yourself to achieve them? 
Guideline 2: A structure of writing journals (Brady \& Kennedy, 2005, p. 68)

My plan is

I found difficult

I enjoyed

\section{REFERENCES}

[1] Badger, L., Dilena, M., Peters, J., Webster, C., \& Weeks, B. (1991). Literacy assessment in practice. [Adelaide]: Education Dept. of S. Aust.

[2] Beech, J. R., \& Singleton, C. (1997) (ed.). The psychological assessment of reading. London; New York: Routledge.

[3] Brady, L., \& Kennedy, K. (2005). Celebrating student achievement: Assessment and reporting. Frenchs Forest, NSW: Prentice Hall.

[4] Bowell, P., \& Heap, B. S. (2001). Planning process drama. London: David Fulton.

[5] Campbell, R., \& Green, D. (2006). Literacies and learners: Current perspectives. Frenchs Forest: Pearson Education.

[6] Curriculum Corporation (Australia). (1997). Assessing as you go: Primary English. Carlton, Vic.: Curriculum Corporation.

[7] Department of Education, Tasmania. (2005). Essential learnings assessing guide. Hobart, Tas: Dept. of Education.

[8] Department of Education of Victoria and Early Childhood Development (2007). Evidence-based research for expert literacy teaching. Paper No. 12.

[9] Edwards-Groves, C. (2003). On task: Focused literacy learning. Newtown, N.S.W.: Primary English Teaching Association.

[10] Hayhoe, M., \& Parker, S. (1992) (ed.). Reassessing language and literacy. Buckingham [England]; Open University Press.

[11] Kulm, G. (1994) (ed.). Mathematics assessment: What works in the classroom. San Francisco: Jossey-Bass.

[12] Little, A. N. (1978). Education policies for multi-racial areas. Inaugural lecture by the Lewisham Professor of Social Administration, University of London, Goldsmiths College.

[13] Owen, P. J. K. (1992). Defining reading standards: Establishing the operational validity of assessments. In M. Hayhoe \& S. Parker (eds.). Reassessing language and literacy (pp. 95-107). Buckingham [England]; Open University Press.

[14] Raggett, M. St J., Tutt, C., \& Raggett, P. (1979) (ed.). Assessment and testing of reading: Problems and practices. London: Ward Lock.

[15] Reynolds, D. (1998). Schooling for literacy: A review of research on teacher effectiveness and school effectiveness and its implications for contemporary educational policies. Educational Review, 50(2), 147-162. Retrieved April 5, 2008, from http://dx.doi.org/10.1080/0013191980500206

[16] Rhodes, L. K. (1993) (ed.). Literacy assessment: A handbook of instruments. Portsmouth, N.H.: Heinemann.

[17] Rowe, K. (2006). Effective teaching practices for students with and without learning difficulties: Issues and implications surrounding key findings and recommendation from the National Inquiry into the Teaching of Literacy. Australian Journal of Learning Disabilities, 11(3), 99-115. Retrieved April 5, 2008, from http://www.acer.edu.au/documents/RoweAJLDPublishedArticleDec2006.pdf.

[18] Sammons, P., Thomas, S., \& Mortimore, P. (1997). Forging links: Effective schools and effective departments. London: Paul Chapman.

[19] Senior, J. (1979). Reading assessment in school. In M. St J. Raggett, C. Tutt \& P. Raggett (ed. pp. 180-192). Assessment and testing of reading: Problems and practices. London: Ward Lock.

[20] Turner, M. (1997). Assessment by educational psychologists. In J. R. Beech \& C. Singleton, The psychological assessment of reading (ed. pp. 49-66). London; New York: Routledge.

[21] Weeden, P., Winter, J., \& Broadfoot, P. (2002). Assessment. London; New York: RoutledgeFalmer.

[22] Winch, G., Johnston, R., March, P., Ljungdahl, L., \& Holliday, M. (2006). Literacy: Reading, writing and children's literature ( 3 ed.). South Melbourne: Oxford University Press.

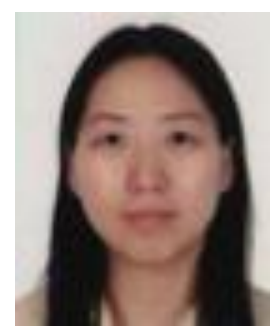

Ruiting Wu A PhD candidate in the Faculty of Education, University of Tasmania, Australia. She is also an experienced School educator, having taught thousands of students from Prep to Year 12. Ms Wu holds a Bachelor of Teaching with Honours and a Master of Education in TESOL from the University of Tasmania, Australia. Her research interest is TESOL, primary teaching, and teaching Chinese as a second language.

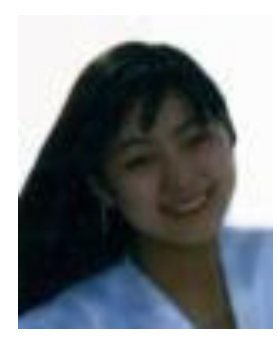

Ruijuan Wu A lecturer in the Faculty of Visual Art, Qing Gong College, Hebei United University, Tang Shan, Hebei, China. She is also an artist in the area of Chinese traditional painting. Her research interest is visual art teaching and Higher education. 


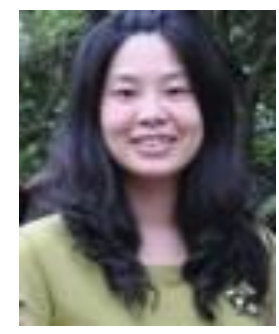

Jinjin Lu A PhD student in the Faculty of Education, University of Tasmania. Her research interest is TESOL and Higher education. She has been working in a Chinese university as a lecturer for more than 7 years. 